\title{
Pusztai Zoltán
}

\section{Milyen válságról van is itt szó?}

\author{
Szentes Tamás: Ki, mi és miért van válságban? \\ A leegyszerüsitö nézetek és szemléletmód kritikája \\ Napvilág Kiadó, Budapest, 2009. 232 oldal, 2400 Ft
}

Szentes Tamás művének célja nemcsak a most megélt globális gazdasági válság tárgyalása, hanem a válságok mögöttes kulturális, morális, politikai, társadalmi rétegeinek feltárása és a köztük lévő összefüggések vizsgálata. Első pillantásra a neoliberális mainstream kritikájának tünhet, ám - akárcsak a szerző más müveiben (pl. Szentes 2009, 2006, 2005) - a mü alapos elolvasásakor egyértelművé válik, hogy kritikai megközelítésként isaz ideológiakritika tárgykörébe sorolandó. Nem egyetlen irányzat ellen szóló írás, s főleg nem kizárólag a neoliberalizmus elleni, hanem a szerző által összes, szélsőségesnek tekintett közgazdasági nézet kritikája, beleértve a szélsőséges nacionalizmust és a szélsőbalt is. Erre azért érdemes külön felhívni a figyelmet, mert mindegyik ideologikussá vált közgazdasági irányzat híveinek szokása azzal vádolni a számára kellemetlen dolgokat kiteregetőket, hogy azok az ellenkező oldal szószólói. Az a tény, hogy mégis elsősorban a neoliberális (a szerző szóhasználatával élve: ultraliberális) monetarista ideológiát „ostorozza”, abból fakad, hogy majelenleg - a mainstream magjaként - ez az uralkodó, legelterjedtebb nézetrendszer, így a többi, ritkábban megjelenő szélsőséges ideológia veszélye korunkban kevésbé releváns.

Szentes Tamás művének első fejezete azokat az akár divatosnak is mondható elméleteket tárgyalja, amelyek mind a külföldi, mind a hazai válságvitákban és tanulmányokban a leggyakrabban fordulnak elö. Ezek az elméletek a legtöbbször nélkülözik a korábbi válságokból leszürhető tanulságokat, s néhány kivételtől eltekintve nagyban leegyszerüsítők és egyoldalúak. Meglehetősen érdekes, hogy ezek a sokat hangoztatott nézetek mindig tökéletes összhangban vannak kinyilvánítójuk eredeti ideológiájával, bármelyik oldalról is érkezzenek, mintha a világgazdaságban beállt „váratlan” fordulat nem késztette volna egyik „szakértőt” sem tételei felülbírálására. Különös, de nem megmagyarázhatatlan. Az „ideológus mentalitás” nem képes, vagy nem hajlandó kritikus gondolkodásra, egyrészt és főleg érdekmotiváltság, másrészt mások nézeteinek megfontolásra sem méltatása, valamint saját megkérdőjelezhetetlen igazságtudatába vetett hite miatt. Ezért nem kell meglepődnünk, hogy csak addig kutatnak, amíg a számukra kedvezö eredményt meg nem találják, hogy majd azt széles körben szétkürtöljék, sajnos túlharsogva a kritikus gondolkodó szerény, megfontolt szavait. 
A fejezet a közgazdasági oktatás kérdéskörével is foglalkozik, mint a leegyszerüsítő nézetek széles körủ elterjedésének egyik okával. A hazai szakoktatás legnagyobb problémája, hogy mindenféle kritikai felülvizsgálat nélkül veszi át a föként amerikai standard alapozó tankönyvek ismeretanyagát. Ezek a tankönyvek ömlesztve tálalják elméleti tételeiket, azok keletkezésének történelmi és gazdasági háttere nélkül, sőt néha még az alkalmazhatósági feltételek is homályban maradnak. Amellett hogy a globalizáció korában már lényegessé vált kérdésekkel nem foglalkoznak részletesen (pl.: a nemzetközi tőkeáramlás elméletével és a nyitott gazdaságok kölcsönhatásainak megértéséhez szükséges mutatókkal), rengeteg felesleges, a gyakorlatban alkalmazhatatlan vagy irreleváns koncepciót tartalmaznak. Szinte kivétel nélkül csak a mainstream iskoláihoz tartozó nézeteket mutatják be, azokat megkérdőjelezhetetlen tényként tálalva, elmulasztva korlátaik feltárását. A piacgazdaság tökéletlenségeinek okait külső okoknak tulajdonítják, azokat a piacgazdaság rendszerén kívül helyezve. Elmossák a különbséget a pénz mint csereeszköz és a tőkeként funkcionáló pénz között, az üzleti etikát csak a vállalatok egymás iránti bizalmának viszonyában értelmezik, és az egyébként egyértelmü fogalmakat, mint tőkés, bérmunkás és profit, olyan semmitmondó eufemizmusokkal váltják fel, mint munkaadó, munkavállaló és vállalati nyereség, a „politikai korrektség” nevében.

Ha a leegyszerüsíto „válságteoretikusok” el is mulasztják a múlt tapasztalatainak figyelembevételét, Szentes Tamás nem így jár el. A második fejezetben ismerteti a válságelméleti klasszikusok tételeit, kezdve Marxszal és Keynesszel, folytatva a posztkeynesiánus reformista irányzattal és befejezve a mai neoliberális monetarista iskola megalapozóival. A leghatásosabb mégis a fejezet vége, ahol szó szerint idézi azoknak a klasszikus liberális közgazdáknak szavait, akikre a mai neoliberális ideológusok oly elöszeretettel hivatkoznak, rámutatva a nagy elődök és névleges utódaik közötti szakadékra.

A negyedik fejezet legalapvetőbb megállapítása, hogy a pénzpiaci válság nemcsak a globális válság előidézője, hanem megjelenési formája is, mondhatjuk úgy, hogy a tünete. Valószínüsíthető, hogy az emberi betegség és tünetének analógiaként való használata nem pusztán belemagyarázás, hanem Szentes részéről is tudatos, ugyanis maga is használja a diagnózis kifejezést Marx elméletére (kiváló diagnosztának nevezi), az élő szervezet kifejezést pedig a társadalomra. Ha tudjuk, hogy a pénzügyi válság tünete a globális gazdasági válságnak, akkor a gondolatot folytatva logikusan következik, hogy a globális gazdasági válság ugyanúgy tünete lehet egy társadalmi válságnak, mert a pénzügyek ugyanúgy csak egy részterülete a gazdaságnak, mint ahogy az egész gazdaság csak egy részterülete a társadalmi folyamatoknak. Ebben az összefüggésben az a gyakran hangoztatott „érv”, hogy a kapitalizmus válságokon keresztül fejlődik, azt jelenti, hogy a kapitalizmus vagy legalábbis az a gazdasági rendszer, amit kapitalizmus néven emlegetnek, egy krónikusan beteg ember, akinek betegségtünetei előjönnek elkerülhetetlenül, időről időre. És minden olyan ideologikus alapú leegyszerüsítő válságkezelési javaslat, ami a válságot tekinti betegségnek, sőt olykor természetes jelenségnek, pusztán tüneti kezelés lesz, ami a problémákat nem oldja meg, csak ideiglenesen elleplezi.

A válságnak nemcsak gazdasági aspektusai vannak, hanem az egész emberi társadalom kultúrája, magatartása, erkölcse is válságban van. Ezeknek tünetei rokonságban állnak a gazdasági szférában jelentkező tünetekkel. A szerző nem tesz kísérletet arra, hogy a társadalmi problémák kezdeteit feltárja, ehelyett magára a betegségre koncentrál, aminek legszembetűnőbb megnyilvánulási formája gazdasági szinten a verseny eltorzulása, egyéni szinten az önzés, társadalmi szinten a felelőtlen individualizmus kultusza. 
A verseny mint fogalom mára már a gyakorlatban elvesztette azt az eredeti latin competitio szóban lévő többletértelmet, ami a közös cél elérése érdekében tett törekvést és együttmüködést jelentette. Különösen veszélyes ez a fogalmi elszegényedés, ha a nemzetek vagy országok versenyképességéről beszélünk, mert ebben a léptékben már nem csak gazdasági terepen lehet versenyezni, itt már nem pusztán áruk adásvételéröl van szó. Épp ez a versenynek az a szintje, ahol az eredeti értelmü nemes versengés a legnagyobb hasznot hozhatja az egész világnak. Ezzel szemben a versenyképesség mint legfőbb „érték” hajszolása közben „megszabadulunk” olyan értékektől, mint a szolidaritás vagy a szociális érzékenység. A verseny már nem is zéróösszegü, hanem kifejezetten negatív összegü játékká válik, mind vállalati, mind országok közötti és regionális szinten. „Egyéni szinten ugyanennek a jelenségnek a másik megnyilvánulása a „légy sikeres!” .(ez az eufemizmus a gyakorlatban „légy gazdagot” jelent) jelszó mögött megbúvó önzés és képmutatás. A nem sikereseket vesztesként bélyegzik meg, úgy, mintha csakis önhibájukból kerültek volna abba a helyzetbe, amiben vannak, és mintha a sikeresek a több pénz felé vezető úton a légüres térben lépkednének, elkendőzve azt a tényt, hogy a magasba vezető lépcső a vesztesek „tetemeiből” épül.

Társadalmi szinten jelenik meg a fékevesztett individualizmus, amikor az egyének már nem a közösség tagjaiként, hanem minden kötöttségtől, erkölcsi és természeti törvény hatásától mentesen élnek. Arról az önző individualizmusról van szó tehát, amely mindent akar és mindent most akar. Ez az, ami a bulvármédiumokból is árad. elyHirdetői a liberalizmus szabadságeszményére hivatkoznak, miközben szabadosságot terjesztenek.

A liberalizmus eszméjét nagyrészt az önmagukat liberálisnak nevező pártpolitikusok járatják le: miközben szólásszabadságot hirdetnek, mindent megtesznek a másképp szólók vagy gondolkodók elhallgattatására. Mint ahogy egyes szociáldemokrata, szocialista pártpolitikusok egyenesen antiszociális gazdaságpolitikai intézkedéseket, „csomagokat” támogatnak, vagy mint ahogy magukat konzervatívnak tartók olyan egykulcsos adórendszer és vagyonadó bevezetése mellett érvelnek, mely leginkább a középosztályt sújtja, lejáratva mindazon eszméket és értékeket, amelyeket névleg felvállalnak. De éppen ennyire lejáratják a hazafiság eszméjét a jobboldali pártok azon vezetői, akik nacionalista demagógiával füszerezve nemzeti érdekről szónokolnak, közben idegengyülöletet keltenek, és csak egyéni érvényesülésüket keresik. Mindezek ellenére, ahogy a szerző felhívja rá figyelmünket, ha csalódunk is azokban, akik az emberi értékek részét képező nemes eszméket kiforgatva azokból ideológiát gyártanak, amelyekre hivatkozva önös érdekeiket érvényesíthetik, még nem kell csalódnunk magukban a tiszta eszmékben.

Szentes válságkezelési javaslata nem korlátozódik pusztán költségvetési kiadási és bevételi tételekre, és pont ezért eléggé általános is. A széles körü morális problémákon felül a válságok, a rendszerszerüen visszatérő világgazdasági válságok fő okának a nemzetközi tulajdonviszonyok, kereskedelem, nemzetközi monetáris kapcsolatok és a fejlődés rögzült vagy egyre súlyosbodó aszimmetriákban megnyilvánuló egyensúlytalanságát tartja. A fentebb bevezetett „betegség” analógiával élve, amíg a világgazdaság testében az ilyen mértékü egyensúlytalanságok léteznek, addig a válságok természetes immunreakcióként jelentkezni fognak, ezért egy végleges kúrának ezeket az aszimmetriákat kell megszüntetnie. Mindaddig azonban, amíg az az ideologikus nézet az uralkodó, mely szerint az aszimmetrikus kapcsolatok hátrányosabb oldalán található országok kizárólag saját maguknak köszönhetik helyzetüket, a globális probléma megoldásához szükséges globális felelősségvállalásra kevés esély mutatkozik. Ennek ellenére akár optimisták is lehetünk, mert ha a döntési helyzetben 
lévő politikusok és „szakérto”” tanácsadóik most nem is változtatnak hozzáállásukon, utódaiknak az eljövendő válságok során még lehet rá lehetőségük, ha lesz még egyáltalán valami, hogy változtatni lehessen.

\section{Hivatkozási lista}

Szentes Tamás [2009]: Megjegyzések a válság gyökereiről és a kiutakról - a leegyszerűsítő nézetek és politikák ellenében. Magyar Tudomány, 170. évf. 5. sz. 604-627. o.

Szentes Tamás (2006): Az állam szerepe a felgyorsult globalizáció korában. Köz-gazdaság: tudományos füzetek, 1. évf. 1. sz. 15-45. o.

Szentes Tamás (2005): Világgazdaságtan. Aula Kiadó, Budapest. 